\title{
Isoflurane exposure regulates the cell viability and BDNF expression of astrocytes via upregulation of TREK-1
}

\author{
CUI-HONG ZHOU ${ }^{1 *}$, YA-HONG ZHANG ${ }^{1 *}$, FEN XUE $^{1 *}$, SHAN-SHAN XUE $^{1}$, \\ YUN-CHUN CHEN $^{1}$, TING GU ${ }^{2}$, ZHENG-WU PENG ${ }^{1}$ and HUA-NING WANG ${ }^{1}$ \\ Departments of ${ }^{1}$ Psychiatry and ${ }^{2}$ Anesthesiology, Xijing Hospital, Fourth Military Medical University, \\ Xi'an, Shaanxi 710032, P.R. China
}

Received January 11, 2017; Accepted July 26, 2017

DOI: $10.3892 / \mathrm{mmr} .2017 .7547$

\begin{abstract}
Neonatal isoflurane exposure in rodents disrupts hippocampal cognitive functions, including learning and memory, and astrocytes may have an important role in this process. However, the molecular mechanisms underlying this disruption are not fully understood. The present study investigated the role of TWIK-related $\mathrm{K}^{+}$channel (TREK-1) in isoflurane-induced cognitive impairment. Lentiviruses were used to overexpress or knockdown TREK-1 in astrocytes exposed to increasing concentrations of isoflurane or $\mathrm{O}_{2}$ for $2 \mathrm{~h}$. Subsequently, the mRNA and protein expression of brain-derived neurotrophic factor (BDNF), caspase-3, Bcl-2-associated X (Bax) and TREK-1 was measured by reverse transcriptionquantitative polymerase chain reaction and western blot analysis, respectively. In addition, cell viability was assessed by a 2-(4-Iodophenyl)-3-(4-nitrophenyl)-5-(2,4-disulfophenyl)$2 \mathrm{H}$-tetrazolium monosodium salt assay. The results demonstrated that, prior to manipulating TREK-1, isoflurane significantly decreased the cell viability and BDNF expression, and increased Bax, caspase-3 and TREK-1 expression was observed. However, TREK-1 overexpression in astrocytes significantly downregulated BDNF expression, and upregulated Bax and caspase-3 expression. Furthermore, lentiviral-mediated short hairpin RNA knockdown of TREK-1
\end{abstract}

Correspondence to: Dr Zheng-Wu Peng or Professor Hua-Ning Wang, Department of Psychiatry, Xijing Hospital, Fourth Military Medical University, 145 Changle West Road, Xi'an, Shaanxi 710032, P.R. China

E-mail: pengzhengwu1446@163.com

E-mail: xskzhu@fmmu.edu.cn

*Contributed equally

Abbreviations: BDNF, brain-derived neurotrophic factor; DMEM, Dulbecco's modified Eagle's medium; FBS, fetal bovine serum; GFAP, glial fibrillary acidic protein; TREK-1, TWIK-related $\mathrm{K}^{+}$channel

Key words: isoflurane, astrocytes, cell viability, brain-derived neurotrophic factor, TWIK-related $\mathrm{K}^{+}$channel effectively inhibited the isoflurane-induced changes in BDNF, Bax and caspase-3 expression. Taken together, the results of the present study indicate that isoflurane-induced cell damage in astrocytes may be associated with TREK-1-mediated inhibition of BDNF and provide a reference for the safe use of isoflurane anesthesia in infants and children.

\section{Introduction}

Isoflurane is commonly employed to maintain general anesthesia during various types of surgery, owing to its properties that allow a precise concentration to be delivered continuously throughout in vivo experiments $(1,2)$. However, isoflurane may induce neurotoxicity, which in turn leads to cognitive dysfunction or learning/memory impairment (3), and postoperative cognitive dysfunction is one of the most common complications characterized by cognitive decline following surgery using isoflurane (4). Notably, early isoflurane exposure may induce long-term learning deficits and cognitive dysfunction in children and rodents $(5,6)$.

Hippocampal neuroplasticity has an important role in cognitive functions such as learning and memory $(7,8)$. Previous studies have demonstrated that decreased hippocampal neurogenesis contributes to spatial learning deficits in aging and animal models of Alzheimer's disease $(9,10)$. In addition, decreased presynaptic and postsynaptic protein expression, fewer synaptic contacts and less efficient synaptic connections induced by adolescent $\Delta 9$-tetrahydrocannabinol treatment are associated with cognitive impairment in adulthood (11). Furthermore, treadmill exercise improves cognitive function by enhancing hippocampal neuroplasticity, including increased expression of brain-derived neurotrophic factor (BDNF) and enhanced cell proliferation in obese mice (12).

Astrocytes, which actively interact with neurons at synapses, are the most abundant cell type in the brain and have an important role in supporting neuronal development $(13,14)$.In addition, astrocytes contribute to synaptic plasticity by secreting factors that increase the number and function of synapses, and also influence synaptic transmission across neuronal circuits (15). Astrocyte-mediated metaplasticity contributes to the hippocampal dysfunction that underlies the impaired cognition involved in several neurological diseases (16). Furthermore, astrocytes are an important intermediary of septal cholinergic 
modulation in the hippocampus, which has an important role in hippocampus-dependent learning and memory (17). Notably, cognitive impairment following isoflurane exposure is associated with impairment of hippocampal activity and function in rodents (18). The majority of studies concerning the cellular mechanisms of isoflurane toxicity have focused on the survival, proliferation, differentiation and migration of hippocampal neurons and neural stem cells $(19,20)$. However, the cellular effects of isoflurane on hippocampal astrocytes and the associated molecular mechanism are not fully understood.

TWIK-related $\mathrm{K}^{+}$channel (TREK-1) is a two-pore domain background $\mathrm{K}^{+}$channel that is essential for cell volume regulation and is therefore involved in the regulation of cell proliferation, necrosis and apoptosis (21). TREK-1 is expressed throughout the brain, particularly in neurons and astrocytes of the cortex, cerebellum and hippocampus (22), and a recent study reported high expression and partial function of TREK-1 in astrocytes (23). Notably, TREK-1 is activated by clinical concentrations of isoflurane (24), and is involved in the effects of isoflurane preconditioning $(25,26)$. A recent study reported that blocking TREK-1 using the sortilin-derived peptide spadin induced an antidepressant-like effect and also augmented protein kinase A-CREB-BDNF signaling in the hippocampus (27). Additionally, the essential role of astrocyte $\mathrm{K}^{+}$channels in central nervous system homeostasis has been confirmed in animal disease models, and emerging evidence indicates that signaling mediated by astrocyte ion channels, such as TREK-1, enables the interaction between astrocytes and neurons, which subsequently regulates synaptic transmission and plasticity (28). Thus, we hypothesize that the activity of TREK-1 and associated factors, such as BDNF in hippocampal astrocytes, may be involved in isoflurane-induced cognitive dysfunction. The present study investigated the effects of different isoflurane dosages on cell viability and the expression of caspase-3, Bcl-2-associated X (Bax) and BDNF in astrocytes following lentiviral-mediated TREK-1 manipulation.

\section{Materials and methods}

Astrocyte isolation and culture. Experiments were approved by the Institutional Animal Care and Use Committee of the Fourth Military Medical University. A total of 4 female and 2 male C57BL/6 J mice $(20.0 \pm 1.2 \mathrm{~g}$ and 22.0 $1.5 \mathrm{~g}$; 7-9 weeks old ) were purchased from the Laboratory Animal Center of the Fourth Military Medical University (Xi'an, China), and were housed on a 12-h light/dark cycle with ad libitum access to food and water and bred within ( 2 female and 1 male in 1 cage) the Laboratory Animal Center of the Fourth Military Medical University. Mouse pups were caged with the mother and siblings under a 12-h light/dark cycle at room temperature maintained at $22^{\circ} \mathrm{C}$.

Astrocytes were harvested from the brains of 10 newborn (1-day-old) mice, as previously described (29-31). Briefly, hippocampi were isolated in ice-cold dissection buffer (Hanks' balanced salt solution; Gibco; Thermo Fisher Scientific, Inc., Waltham, MA, USA) under a stereomicroscope. After the meninges were removed, single cell suspensions were obtained by mechanical dissociation. After filtering with a 200 molybdenum wire mesh screen, cells were rinsed and resuspended in Dulbecco's modified Eagle's medium (DMEM)
(Gibco; Thermo Fisher Scientific, Inc., Waltham, MA, USA) with $10 \%$ fetal bovine serum (FBS) (Gibco; Thermo Fisher Scientific, Inc.) and plated in $75 \mathrm{~cm}^{2}$ flasks coated with poly-L-lysine (Corning Incorporated, Corning, NY, USA). Cells were incubated at $37^{\circ} \mathrm{C}$ with $5 \% \mathrm{CO}_{2}$ until $90 \%$ confluent. The medium was replenished 2 days after plating and changed every 2 days. Astrocyte-enriched cultures were obtained by shaking mixed glial cultures at a speed of $240 \mathrm{rpm}$ to remove less adhesive microglia and other cells for $24 \mathrm{~h}$ after 12 days of incubation. Subsequently, astrocytes were digested with $0.25 \%$ trypsin and $1 \mathrm{mM}$-EDTA, split into 6-well or 12-well plates and incubated for $\sim 3$ days at $37^{\circ} \mathrm{C}$ prior to experiments.

Isoflurane administration. Cells were placed on 6-well plates at density of $3 \times 10^{5}$ per well and tand cultured in DMEM supplemented with $10 \% \mathrm{FBS}$ in an incubator with $5 \% \mathrm{CO}_{2}$ at $37^{\circ} \mathrm{C}$ for $\sim 3$ days, which was followed by exposure to different concentrations of isoflurane according to the clinical concentration of isoflurane and previous studies $(32,33)$. Briefly, identical airtight chambers (Billups-Rothenberg, Inc., Del Mar, CA, USA) and content-certified gas canisters containing $21 \%$ oxygen, and $79 \%$ nitrogen were equilibrated to $37^{\circ} \mathrm{C}$ overnight in a heated room. Subsequently, plates were randomly placed in airtight chambers flushed with control gas (100\% oxygen) at $4 \mathrm{l} / \mathrm{min}$ for $\sim 5$ min or flushed with gas containing isoflurane (oxygen with isoflurane) at the same flow rate until the isoflurane concentrations in the chamber reached the set value and remained stable for $2 \mathrm{~h}$ at $0.5,1.0$ or 1.5 minimum alveolar concentration (MAC) isoflurane $(0.7 \%, 1.4 \%$ and $2.1 \%$, respectively). The chamber was then sealed and placed in an incubator at $37^{\circ} \mathrm{C}$ for $2 \mathrm{~h}$. Afterwards, the cells were removed and returned to a normal culture (incubated at $37^{\circ} \mathrm{C}$ with $5 \% \mathrm{CO}_{2}$ ) at atmospheric conditions for $2 \mathrm{~h}$ for cell viability analysis and other assays.

Cell viability determination. Cell viability was determined using a 2-(4-Iodophenyl)-3-(4-nitrophenyl)-5-(2,4-disulfo phenyl)-2H-tetrazolium monosodium salt (WST-1) assay kit (Cell proliferation Reagent WST-1; 11644807 001; Roche Diagnostics, Indianapolis, IN, USA) according to the manufacturer's instructions. In a preliminary experiment, three different WST-1 concentrations (WST-1/cell growth medium, 100, 200 and $300 \mu \mathrm{l} / \mathrm{ml}$ ) were employed with three different treatment durations (1, 2 and $3 \mathrm{~h}$ ), and the results demonstrated that there was no significant difference in the cell viability between cells treated with different WST-1 concentrations and for different durations. Therefore, for subsequent cell viability experiments, cells were treated with $200 \mu \mathrm{l} / \mathrm{ml}$ WST-1 for $2 \mathrm{~h}$, which was recommended in the manufacturer's protocol. Briefly, $200 \mu \mathrm{l}$ WST-1 (Cell proliferation Reagent WST-1; 11644807 001, Roche Diagnostics) was added to each well (with $3 \times 10^{5}$ cells in $1 \mathrm{ml}$ growth medium) prior to exposure to isoflurane, and cultures were treated with isoflurane or $\mathrm{O}_{2}$ (control group) for $2 \mathrm{~h}$ at $37^{\circ} \mathrm{C}$. The optical density was measured at $450 \mathrm{~nm}$ using a microplate reader (Bio-Rad Laboratories, Inc., Hercules, CA, USA) immediately following isoflurane administration. Data are presented as the mean of three independent experiments that were performed at least five times.

Immunocytochemistry. To verify the identity of astrocytes, primary cultures were placed on poly-L-lysine-coated 
coverslips in 12 -well plates until $80 \%$ confluent. Astrocytes were fixed in $4 \%$ paraformaldehyde for $30 \mathrm{~min}$ at $4^{\circ} \mathrm{C}$ and permeabilized in 0.3\% Triton-X-100 (T9284; Sigma-Aldrich; Merck KGaA, Darmstadt, Germany) for $10 \mathrm{~min}$ at room temperature $\left(23^{\circ} \mathrm{C}\right)$ prior to immunocytochemistry. Subsequently, astrocytes were blocked in $5 \%(\mathrm{w} / \mathrm{v})$ bovine serum albumin (Sigma-Aldrich; Merck KGaA) for $30 \mathrm{~min}$ at room temperature. The primary antibody mouse anti-glial fibrillary acidic protein (GFAP; 1:1,000; SAB5201113; Sigma-Aldrich; Merck KGaA) was diluted in immune buffer (1\% w/v bovine serum albumin and $0.3 \%$ Triton-X-100) and incubated with astrocytes overnight at $4^{\circ} \mathrm{C}$. Subsequently, cells were washed with PBS and incubated for $2 \mathrm{~h}$ in the dark at room temperature in the presence of fluorescent secondary antibodies (Alexa Fluor 594 donkey anti-mouse IgG; 1:1,000; A-21203; Invitrogen; Thermo Fisher Scientific, Inc.). Cells were then incubated with DAPI for $20 \mathrm{~min}$ at room temperature to stain the cellular nuclei. Finally, the coverslips were mounted onto slides in PBS/glycerol (vol/vol, 1:1). The preparations were analyzed under a laser scanning confocal microscope (FV-1000; Olympus Corporation, Tokyo, Japan), and the positive cells were measured and quantitated using Image-Pro Plus software (version 6.0, Media Cybernetics, Inc., Rockville, MD, USA) in 6 fields of view.

Virus infection and reverse transcription-quantitative polymerase chain reaction (RT-qPCR) analysis. Lentiviruses expressing a short hairpin RNA (shRNA) targeting the sequence of the TREK-1 gene (Lv-shRNA-TREK-1), a negative control lentivirus (Lv-shRNA-sham), lentivirus expressing TREK-1 (Plenti-TREK-1-GFP) and a GFP control lentivirus (Plenti-sham-GFP) were all purchased from Shanghai Genechem Co., Ltd. (Shanghai, China). Growing cells were seeded at $2 \times 10^{5}$ cells/well into 6 -well plates or $1 \times 10^{5}$ cells/well into 12 -well plates and incubated at $37^{\circ} \mathrm{C}$ for 3 days. The transfection was performed using polybrene reagent (Shanghai Genechem Co., Ltd.), according to the manufacturer's protocol. Briefly, $20 \mu \mathrm{l}$ of polybrene $(5 \mathrm{mg} / \mathrm{ml})$ and $50 \mu \mathrm{l}$ of virus (storage concentration of virus: $5.0 \times 10^{8} \mathrm{TU} / \mathrm{ml}$ for Lv-shRNA-TREK-1, $4.5 \times 10^{8} \mathrm{TU} / \mathrm{ml}$ for Lv-shRNA-sham, $4.9 \times 10^{8} \mathrm{TU} / \mathrm{ml}$ for Plenti-TREK-1-GFP and 5.0x10 8 TU/ml for Plenti-sham-GFP) into $20 \mathrm{ml}$ DMEM medium (with $10 \% \mathrm{FBS}$ ) were mix gently, and the cells were cultured with the mixture medium $(1 \mathrm{ml} /$ well for 6 -well plates and $0.5 \mathrm{ml} /$ well for 12 -well plates) at $37^{\circ} \mathrm{C}$ for $24 \mathrm{~h}$. At $24 \mathrm{~h}$ after infection, the transfection mixture was replaced with fresh medium (DMEM $+10 \% \mathrm{FBS})$ and cultured for a further $48 \mathrm{~h}$ at $37^{\circ} \mathrm{C}$. Then, Cells in 12-well plates were fixed in $4 \%$ paraformaldehyde and stained with GFAP antibody to confirm the virus transfection effects by immuno-fluorescent assay as before.

Total RNA was isolated from cells using RNAiso Plus (Takara Bio, Inc., Otsu, Japan) and reverse transcribed $\left(37^{\circ} \mathrm{C}\right.$ for $15 \mathrm{~min} ; 85^{\circ} \mathrm{C}$ for $5 \mathrm{sec}$ and $4^{\circ} \mathrm{C}$ for $10 \mathrm{~min}$ ) with a Prime-Script RT reagent kit (Takara Bio, Inc.). Subsequently, the cDNA was quantified by qPCR with SYBR Premix Ex Taq (Takara Bio, Inc., Otsu, Japan). The following primer sequences were used: Mice GAPDH forward, 5'-CCAATG TGTCCGTCGTGGATCT-3' and reverse, 5'-GTTGAAGTC GCAGGAGACAACC-3'; BDNF forward, 5'-TCATACTTC GGTTGCATGAAGG-3' and reverse, 5'-ACACCTGGGTAG
GCCAAGTT-3'; caspase-3 forward, 5'-AACCAGATCACA AACTTCTGCAAA-3' and reverse, 5'-TGGAGTCCAGTG AACTTTCTTCAG-3'; and TREK-1 forward, 5'-TCAAGC ACATAGAAGGCTGG-3' and reverse, 5'-ACGGATGTG GCAGCGTGG-3'. The two-step qPCR program used was as follows: 1 cycle of $95^{\circ} \mathrm{C}$ for $30 \mathrm{sec}$, followed by 40 cycles of $95^{\circ} \mathrm{C}$ for $5 \mathrm{sec}, 60^{\circ} \mathrm{C}$ for $30 \mathrm{sec}$, and 1 cycle of $95^{\circ} \mathrm{C}$ for $15 \mathrm{sec}$, then maintained at $4^{\circ} \mathrm{C}$. Subsequently, the relative changes in gene expression of BDNF, TREK-1, caspase-3 were analyzed by $2^{-\Delta \Delta \mathrm{Cq}}$ method (34).

Western blot analysis. Cell samples were harvested from culture plates following isoflurane exposure for the determination of TREK-1, BDNF, caspase-3 and Bax protein levels. Cells were lysed in buffer composed of $62.5 \mathrm{mM}$ Tris- $\mathrm{HCl}$, $2 \% \mathrm{w} / \mathrm{v}$ SDS, $10 \%$ glycerol, $50 \mathrm{mM}$ dithiothreitol and $0.1 \% \mathrm{w} / \mathrm{v}$ bromphenol blue. Insoluble materials were separated by centrifugation at $4^{\circ} \mathrm{C}, 12,000 \mathrm{x}$ g for $10 \mathrm{~min}$ and protein levels in the supernatant were measured by the BCA method (Invitrogen; Thermo Fisher Scientific, Inc.), and then the supernatant was heated to $100^{\circ} \mathrm{C}$ for $10 \mathrm{~min}$ and then cooled on ice for $30 \mathrm{~min}$. Electrophoresis was performed by SDS-PAGE using a $10 \%$ polyacrylamide gel $(40 \mu \mathrm{g}$ of total protein per lane). Separated proteins were transferred onto nitrocellulose membranes, which were subsequently blocked with 5\% non-fat milk solution for $1 \mathrm{~h}$ at room temperature under gentle agitation. After washing three times in TBS with $0.5 \%$ Tween-20 (TBST; 10 min per wash), membranes were incubated with primary antibodies against TREK-1 (1:500; Sigma-Aldrich; Merck KGaA), BDNF (1:5,000; Cell Signaling Technology, Inc., Danvers, MA, USA), caspase-3 (1:500; Abcam, Cambridge, UK), Bax (1:1,000; Abcam) and $\beta$-actin $(1: 2,000 ;$ Abcam $)$ overnight at $4^{\circ} \mathrm{C}$. The membranes were washed three times in TBS and incubated with peroxidase-conjugated antibodies in TBST for $1 \mathrm{~h}$ (donkey anti-rabbit IgG; 1:10,000; Abcam). Subsequently, membranes were washed three times for $10 \mathrm{~min}$ in TBST, and immunoreactive bands were detected using SuperSignal West Pico Chemiluminescent Substrate (34077; Thermo Fisher Scientific, Inc.), visualized on X-ray films and densitometric analysis was performed with Bio-Rad Quantity One1-D Analysis Software (1709600; Bio-Rad Laboratories, Inc., Hercules, CA, USA).

Statistical analysis. Statistical analysis was performed using SPSS 17.0 (SPSS, Inc., Chicago, IL, USA). Data are presented as the mean + standard deviation. Comparisons were performed using a one-way or two-way analysis of variance followed by Tukey post hoc tests for multi-group comparisons, and isoflurane concentration was the factor assessed. $\mathrm{P}<0.05$ was considered to indicate a statistically significant difference.

\section{Results}

Isoflurane exposure decreases cell viability in astrocytes in vitro. In the present study, primary mouse astrocytes were isolated and cultured on poly-D-lysine-coated coverslips. After 7 days of culture, the cellular homogeneity of the primary cultures was evaluated using immunocytochemistry for the glial marker GFAP, and cells exhibited immunoreactivity for GFAP (Fig. 1A). Following treatment of the cultured 


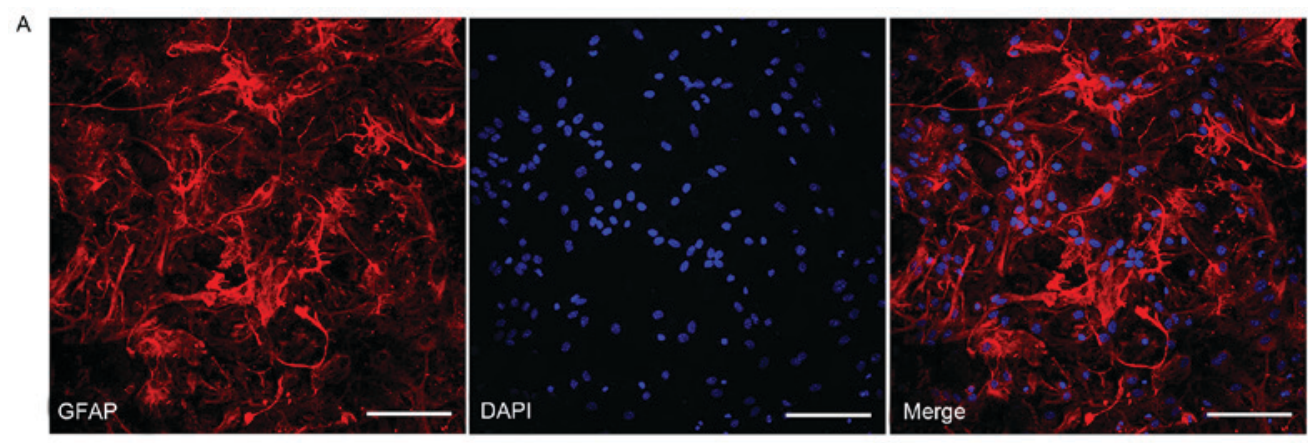

B
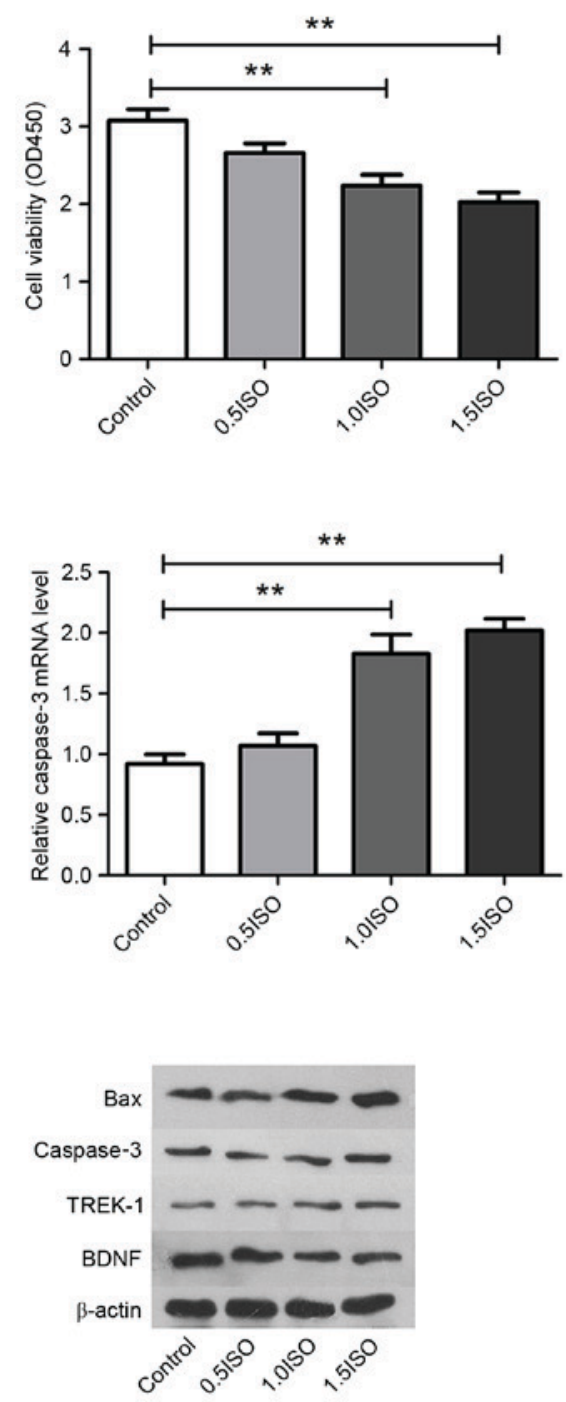

C

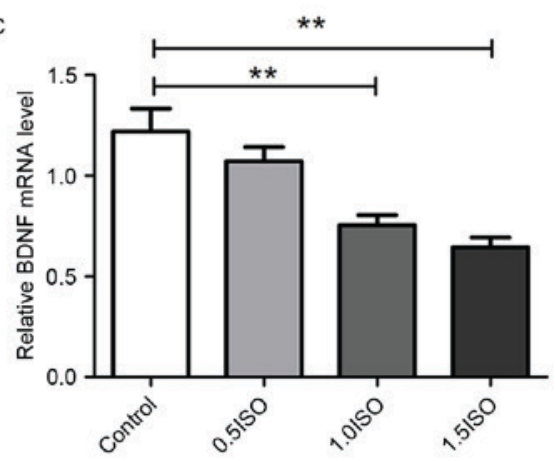

$\mathrm{E}$
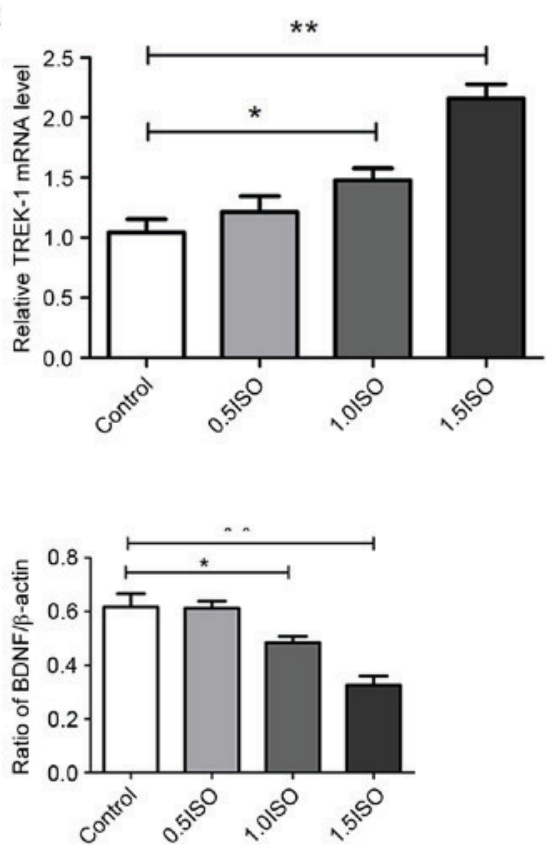
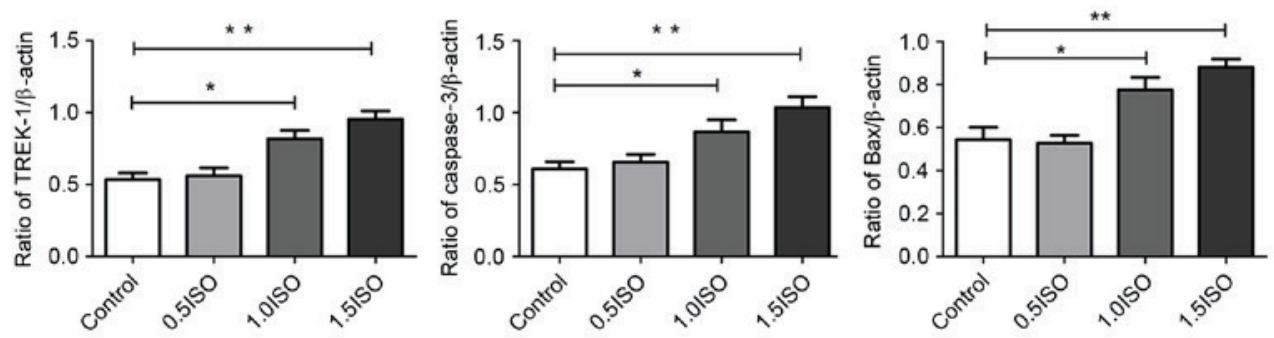

Figure 1. Effect of isoflurane exposure on the cell viability and gene expression of astrocytes. (A) Representative microphotographs of GFAP staining (red), DAPI staining (blue) and their merged images. Scale bar, $200 \mu \mathrm{m}$. (B) Histograms demonstrating the effect of $0.5(0.7 \%)$, $1.0(1.4 \%)$ and $1.5(2.1 \%)$ minimum alveolar concentration of isoflurane on the cell viability. mRNA expression of (C) BDNF, (D) caspase-3 and (E) TREK-1, as determined via reverse transcription-quantitative polymerase chain reaction. (F) Representative protein bands and densitometric analysis of BDNF, TREK-1, caspase-3 and Bax expression relative to $\beta$-actin expression. $\mathrm{n}=6$ per group; ${ }^{*} \mathrm{P}<0.05$ and ${ }^{* *} \mathrm{P}<0.01$, as indicated. GFAP, glial fibrillary acidic protein; BDNF, brain-derived neurotrophic factor; TREK-1, TWIK-related $\mathrm{K}^{+}$channel; Bax, Bcl-2-associated X; OD, optical density; ISO, isoflurane. 
A

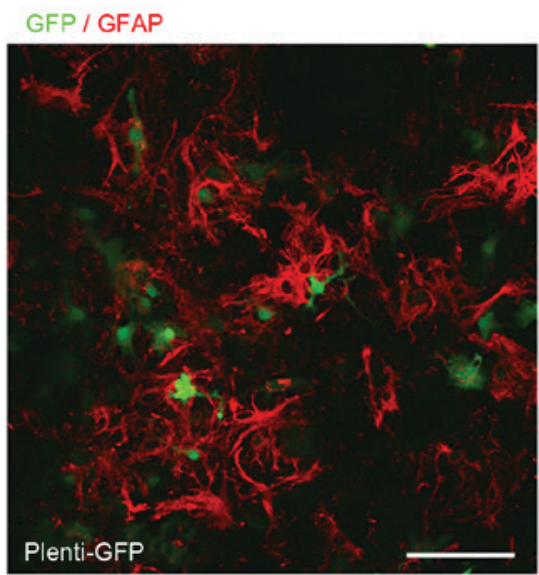

C

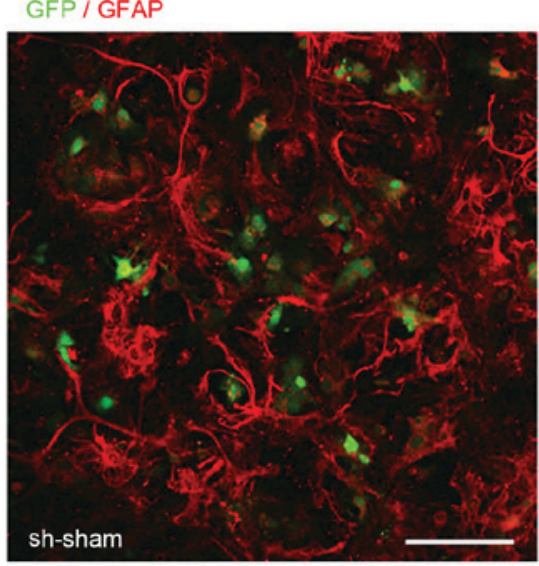

B

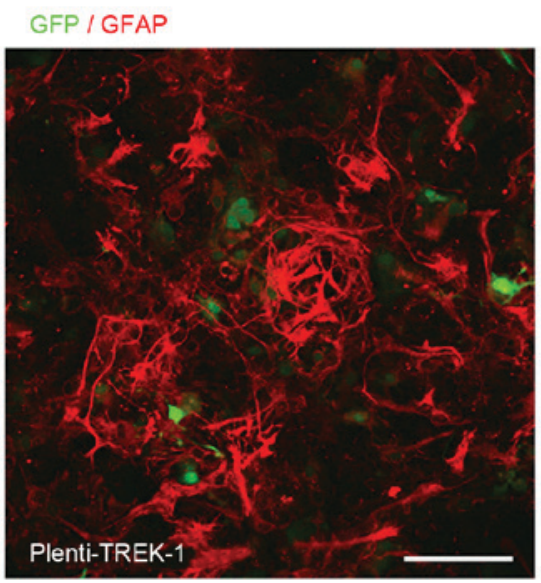

D

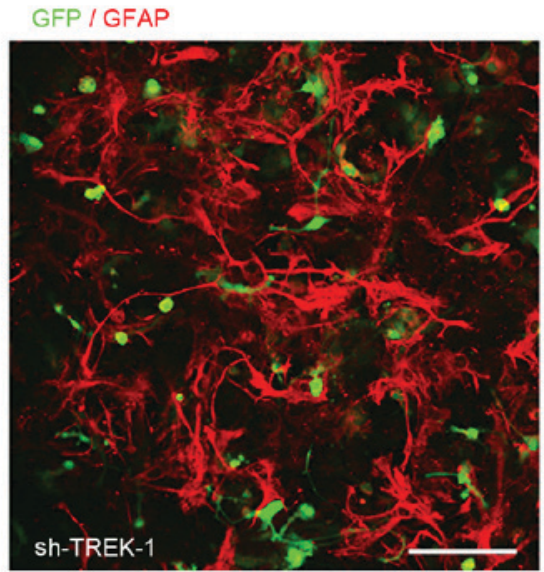

Figure 2. Microphotographs indicating GFAP staining (red) and lentivirus infection (green) in astrocytes. Astrocytes were successfully infected with (A) Plenti-GFP lentivirus as an overexpression control, (B) Plenti-TREK-1-GFP lentivirus for TREK-1 overexpression, (C) shRNA-sham-GFP lentivirus as a knockdown control and (D) shRNA-TREK-1-GFP lentivirus for knockdown of TREK-1. Scale bar, $200 \mu \mathrm{m}$. GFAP, glial fibrillary acidic protein; GFP, green fluorescent protein; TREK-1, TWIK-related $\mathrm{K}^{+}$channel; shRNA, short hairpin RNA.

cells with different concentrations of isoflurane for $2 \mathrm{~h}$, cell viability was detected in a WST-1 assay. Compared with the control group, isoflurane exposure at $0.5 \mathrm{MAC}$ had no effect on the viability of astrocytes. By contrast, 1.0 and $1.5 \mathrm{MAC}$ isoflurane treatments resulted in a significant reduction in cell viability compared with the control group ( $\mathrm{P}<0.01$; Fig. 1B).

Isoflurane exposure decreases BDNF levels and increases Bax, caspase- 3 and TREK-1 expression in astrocytes. To investigate the potential molecular mechanism of the effects of isoflurane in astrocytes, following treatment with different concentrations of isoflurane for $2 \mathrm{~h}, \mathrm{RT}-\mathrm{qPCR}$ and western blot analysis were performed to evaluate the expression of BDNF, caspase-3, Bax and TREK-1. As demonstrated in Fig. 1C-F, in comparison with the control group, the mRNA and protein expression of BDNF was significantly decreased in the 1.0 MAC $(\mathrm{P}<0.05)$ and 1.5 MAC $(\mathrm{P}<0.01)$ isoflurane-treated groups. The mRNA and protein expression of caspase- 3 , and the protein expression of Bax, increased significantly in the 1.0 MAC $(\mathrm{P}<0.05)$ and 1.5 MAC $(\mathrm{P}<0.01)$ isoflurane-treated groups. Furthermore, the mRNA and protein expression of TREK-1 increased significantly in the 1.0 MAC $(\mathrm{P}<0.05)$ and 1.5 MAC $(\mathrm{P}<0.01)$ isoflurane-treated groups. No significant differences were observed between the 0.5 MAC isoflurane-treated group and the control group for any genes. These results indicate that isoflurane administration may promote TREK-1 activity and apoptosis in astrocytes, and inhibit BDNF expression.

Overexpression of TREK-1 downregulates BDNF, and upregulates Bax and caspase-3. To investigate whether the aforementioned effects of isoflurane in astrocytes were due to the upregulation of TREK-1, the present study overexpressed and knocked down TREK-1 in cultured astrocytes via lentivirus infection (Fig. 2), and detected the mRNA and/or protein expression of BDNF, Bax and caspase-3. As demonstrated in Fig. 3, Plenti-TREK-1-GFP infection significantly increased TREK-1 expression in astrocytes compared with Plenti-sham-GFP infection cells $(\mathrm{P}<0.05)$, and TREK-1 overexpression exhibited similar effects to the isoflurane-dependent changes in the expression of BDNF, Bax and caspase-3, as TREK-1 overexpression reduced the expression of BDNF, and increased the expression of Bax and caspase-3, which was also observed for isoflurane treatment in Fig. 1C-F. Compared with the Plenti-sham-GFP group, the BDNF mRNA and protein expression significantly decreased $(\mathrm{P}<0.05)$, while the Bax and caspase-3 expression was significantly increased $(\mathrm{P}<0.05)$ in the group infected with Plenti-TREK-1-GFP. These results indicate that TREK-1 may have an important role in BDNF expression and apoptosis in astrocytes. 


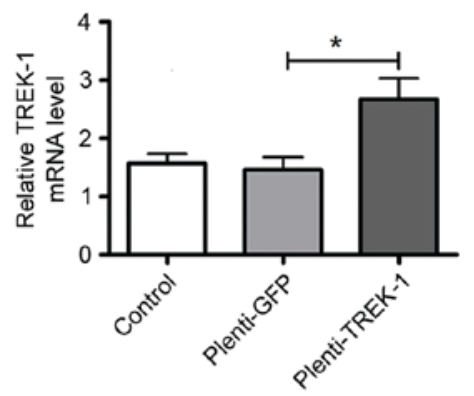

D

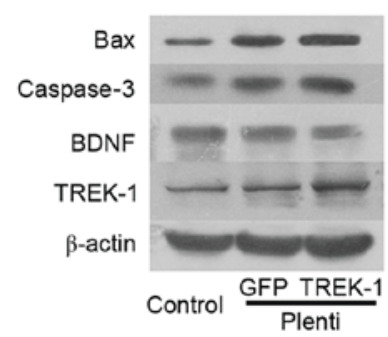

F

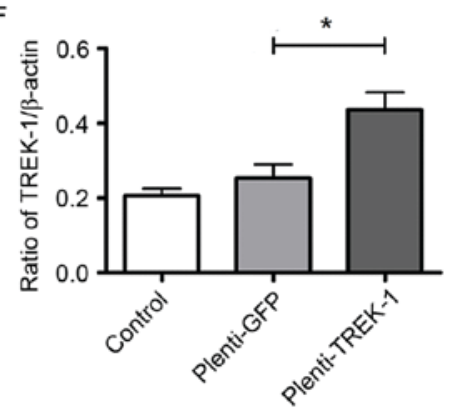

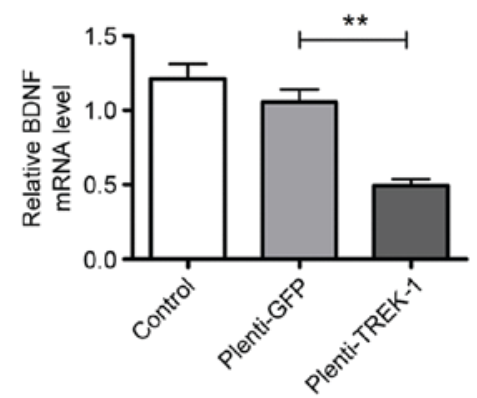

$\mathrm{E}$
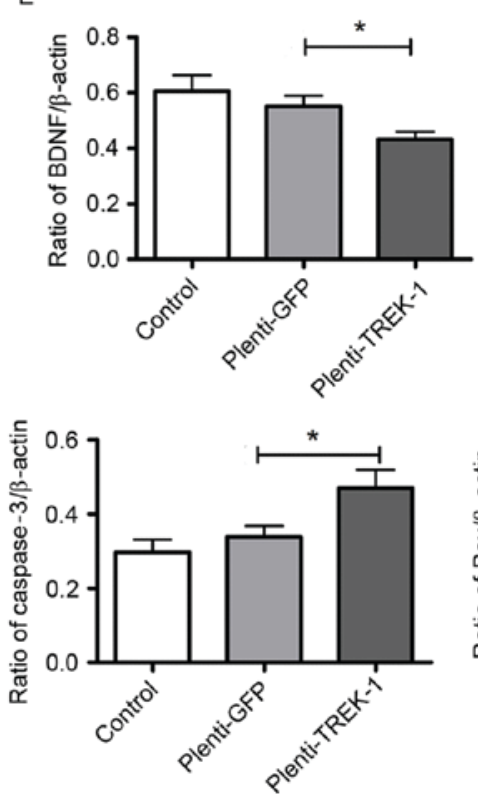
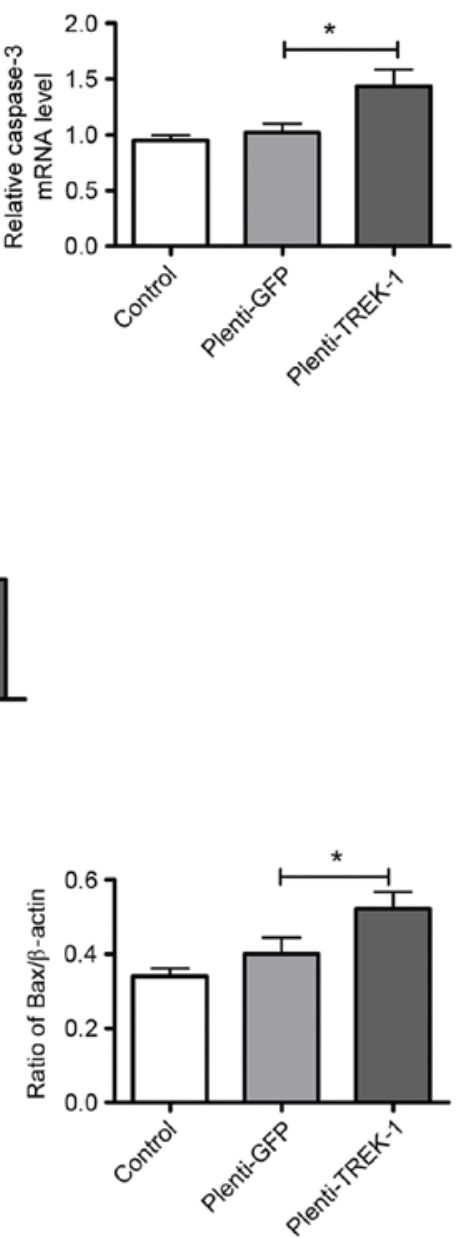

Figure 3. Overexpression of TREK-1 downregulates BDNF, and upregulates Bax and caspase-3 expression. Effect of Plenti-TREK-1-GFP infection on (A) TREK-1, (B) BDNF and (C) caspase-3 mRNA levels in astrocytes. (D) Representative protein bands for Bax, caspase-3, BDNF, TREK-1 and $\beta$-actin in sham and TREK-1 overexpression lentivirus-transfected cells. (E) Plenti-TREK-1-GFP infection decreased the protein expression of BDNF in astrocytes. (F) Plenti-TREK-1-GFP infection increased the protein expression of TREK-1, caspase-3 and Bax in astrocytes. $\mathrm{n}=6$ per group; ${ }^{*}<0.05$ and ** $\mathrm{P}<0.01$, as indicated. TREK-1, TWIK-related $\mathrm{K}^{+}$channel; BDNF, brain-derived neurotrophic factor; Bax, Bcl-2-associated X; GFP, green fluorescent protein.

TREK-1 knockdown in astrocytes inhibits isofluranedependent changes in BDNF, Bax, and caspase-3. To determine whether suppressing TREK-1 expression may attenuate the effects of isoflurane in astrocytes, cultured astrocytes were infected with Lv-shRNA-TREK-1 and Lv-shRNA-sham prior to isoflurane administration (Fig. 2). As demonstrated in Fig. 4, Lv-shRNA-TREK-1 infection significantly decreased TREK-1 mRNA and protein expression $(\mathrm{P}<0.05)$ in astrocytes compared with Lv-shRNA-sham cells, and inhibited the effect of 1.0 and 1.5 MAC isoflurane on the expression of TREK-1, BDNF, Bax and caspase-3 $(\mathrm{P}<0.05)$.

\section{Discussion}

Anesthetic pharmacological agents are widely used clinically for a controlled and reversible loss of consciousness during surgery, which allows millions of individuals to safely undergo surgery (35). However, the side effects on brain development following exposure to general anesthetics are attracting increased attention (36). Isoflurane is a commonly used inhalation anesthetic, and treatment with 1.4-1.7\% isoflurane for $2 \mathrm{~h}$ was reported to reduce acetylcholine levels in the brain and result in learning/memory impairment in rats (32). In addition, exposure to high concentrations of isoflurane (1.0 MAC) for $4 \mathrm{~h}$ induced caspase-3 and extracellular signal-regulated kinase $1 / 2$ activation, and inhibited N-methyl-D-aspartate (NMDA) receptor subunit NR2B protein expression, leading to an impairment of spatial learning performance in young adult C57BL/6 mice (33). Furthermore, neonatal isoflurane exposure was demonstrated to disrupt hippocampal functions such as learning and memory in humans (37). The mechanisms of isoflurane-induced cognitive impairment are poorly understood. Potential candidate mechanisms include an apoptotic cytotoxic effect (38-40) or a sublethal alteration in circuit formation (41-43). Previous studies have indicated that cognitive impairment following isoflurane exposure is directly associated with its effects on synaptic plasticity $(19,20,44)$.

Currently, increasing evidence demonstrates that astrocytes are responsible for controlling the formation, maturation, 
A

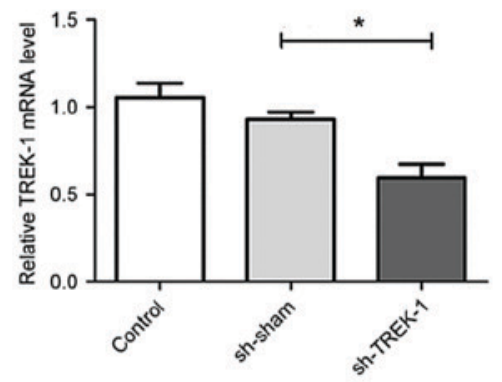

C

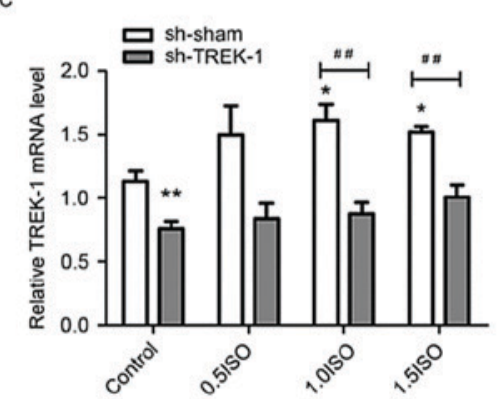

F
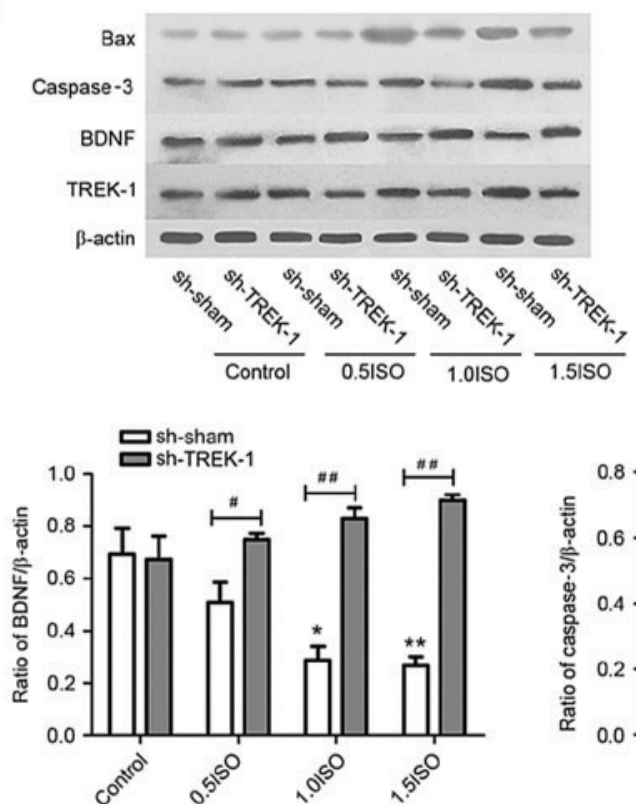

B

D
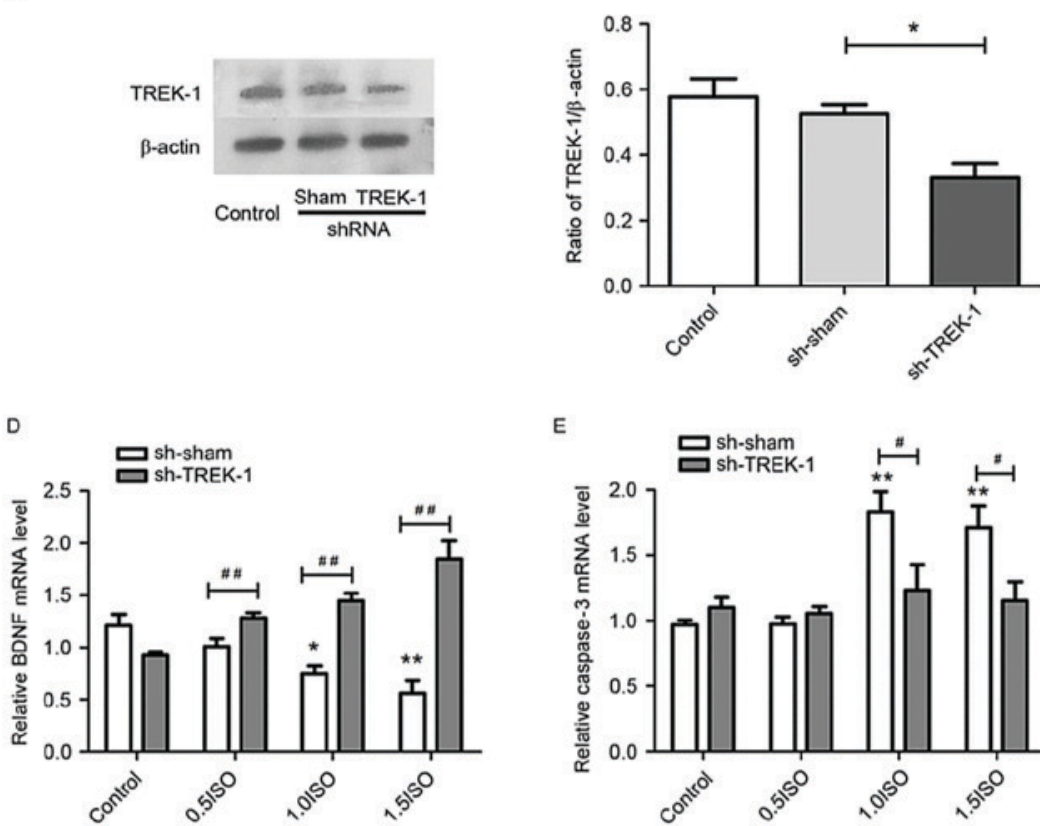

E
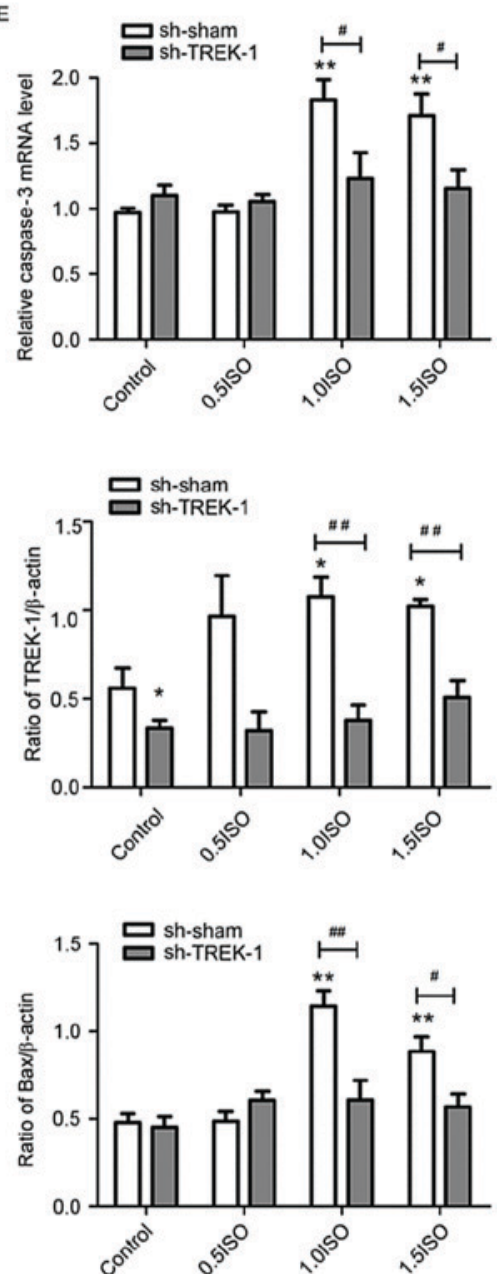

Figure 4. TREK-1 knockdown in astrocytes inhibited isoflurane-dependent changes in BDNF, Bax and caspase-3 expression. Evaluation of (A) mRNA and (B) protein levels of TREK-1 in astrocytes following Lv-shRNA-TREK-1 infection. mRNA levels of (C) TREK-1, (D) BDNF, and (E) caspase-3 in Lv-shRNA-TREK-1 infected astrocytes following exposure to $0.5(0.7 \%), 1.0(1.4 \%)$ and $1.5(2.1 \%)$ MAC isoflurane. (F) Representative protein bands and densitometric analysis of TREK-1, BDNF, caspase-3 and Bax expression relative to $\beta$-actin in Lv-shRNA-TREK-1 infected astrocytes following exposure to $0.5,1.0$ and $1.5 \mathrm{MAC}$ isoflurane. $\mathrm{n}=6$ per group; ${ }^{*} \mathrm{P}<0.05$ and ${ }^{* *} \mathrm{P}<0.01$ vs. control; ${ }^{\#} \mathrm{P}<0.05$ and ${ }^{\# \#} \mathrm{P}<0.01$ vs. sh-sham. TREK-1, TWIK-related $\mathrm{K}^{+}$channel; BDNF, brain-derived neurotrophic factor; Bax, Bcl-2-associated X; Lv, lentivirus; shRNA, short hairpin RNA; MAC, minimum alveolar concentration; sh-, shRNA; ISO, isoflurane.

function and elimination of synapses, processes that are vital for the neural circuit formation and the processing of information in the brain $(45,46)$. As a result, astrocyte dysfunction is reported to be involved in several brain disorders that are associated with cognitive impairment, therefore, astrocytes are considered to have a number of roles in addition to their role in supporting cells $(47,48)$ Notably, previous studies have demonstrated that isoflurane markedly disrupted the response of astrocytes to neuronal activity by suppression of calcium transients in astrocytes (49), and astrocytes protected against isoflurane-induced neurotoxicity by buffering pro-BDNF (50). Additionally, isoflurane alters the ability of cultured astrocytes to support neuronal growth (51). In the present study, the results demonstrated that brief clinical doses of isoflurane (1.0 MAC or 1.5 MAC for $2 \mathrm{~h}$ ) significantly decreased astrocyte viability, and this disruption may be critically involved in the cognitive impairment previously reported following isoflurane exposure. 
It is established that astrocytes synthesize and secrete various cytokines to regulate neural plasticity, which include BDNF and glial cell line-derived neurotrophic factor (GDNF) (52,53). BDNF belongs to the nerve growth factor superfamily, which is essential for neuronal differentiation, survival and hippocampal synaptic plasticity, and is associated with cognitive functions such as learning and memory (54). Previous studies have indicated that the age-associated decline in BDNF signaling contributes to age-associated memory deficits and cognitive dysfunction $(55,56)$, and decreased BDNF expression in the brain was reported to be associated with the severity of cognitive impairment (57). By contrast, a previous study indicated that increased BDNF expression may have an essential role in the recovery process of cognitive function following injury to the adult central nervous system (58), and intracranial BDNF injection effectively improved cognitive skill in rats with axonal injury (59). Another study also reported that exposure to an enriched environment restored cognitive impairment induced by chronic cerebral hypoperfusion by upregulating the protein levels of BDNF and NMDA receptor subunit 1 (60). Furthermore, the BDNF signaling pathway is considered to be involved in the cognitive deficits of aging mice (61), and in isoflurane-induced apoptosis in the developing rat brain (62). Xu et al (63) reported that BDNF was involved in hippocampal cell apoptosis, and reduced BNDF levels promoted hippocampal neuronal apoptosis in zinc deficient mice cell due to upregulation of Bax and caspase-3 expression. Previous reports also demonstrated that isoflurane exposure reduced the expression of BDNF, and increased caspase- 3 and Bax expression in the hippocampus, which contributed to isoflurane-induced neuronal apoptosis and cognitive impairments in rats $(64,65)$.

GDNF belongs to the transforming growth factor- $\beta$ superfamily and has an important role in the development of the dopaminergic nigrostriatal system, and astrocyte-derived GDNF is a potent inhibitor of microglial activation (66). However, limited evidence concerning the roles of GDNF in anesthetic-induced cognitive impairment is available. The present study demonstrated that isoflurane decreased BDNF, and increased Bax and caspase-3 expression in cultured astrocytes, which is consistent with the results of previous studies $(62,67,68)$. Furthermore, the results of the current study indicate that isoflurane exposure-induced astrocyte apoptosis may be associated with the downregulation of BDNF expression. However, the potential role of GDNF in isoflurane-induced neurological damage in the hippocampus is unclear and requires further investigation.

$\mathrm{K}^{+}$channels containing a two-pore domain $(\mathrm{K} 2 \mathrm{p})$ are a large family of hyperpolarizing channels that produce background currents that prevent the depolarization of membranes and cell excitability. These $\mathrm{K}^{+}$channels have functions in the cellular mechanisms of apoptosis, vasodilatation, anesthesia, pain, neuroprotection and in the pathomechanism of cognitive deficits (21). TREK-1 is a member of the TREK subfamily of $\mathrm{K} 2 \mathrm{p}$ channels, which are expressed throughout the central nervous system and activated by polyunsaturated fatty acids and lysophospholipids, and inhibited by neurotransmitters (69). TREK-1 may also be activated by volatile anesthetics and may be an important target in the action of drugs such as isoflurane (70). Several studies have demonstrated that TREK-1 is involved in cognitive deficits (71-73). The results of the current study indicate that isoflurane administration in vitro significantly upregulated TREK-1 expression in astrocytes. Furthermore, overexpression of TREK-1 in astrocytes downregulated BDNF, and upregulated Bax and caspase-3, while TREK-1 shRNA effectively reversed the isoflurane-dependent changes in BDNF, Bax and caspase-3 expression. These results indicate that isoflurane exposure disrupts astrocyte viability and BDNF expression, and induces apoptosis, and these effects may be mediated via the TREK-1 signaling pathway.

However, certain studies have reported that isoflurane preconditioning or postconditioning may provide neuroprotection against various damaging insults $(74,75)$. Thus, the role of isoflurane in brain development and function remains controversial. Differences in the concentration and duration time of isoflurane exposure, as well as differences between in vitro and in vivo experimentation, may have contributed to these discrepancies. However, the present study did not investigate the roles of isoflurane and TREK-1 in vivo, which is a potential limitation of the present study.

In conclusion, the results of the current study demonstrated that brief exposure to isoflurane at 1.0 MAC or 1.5 MAC for $2 \mathrm{~h}$ increased the expression of TREK-1 and the apoptosis-associated proteins caspase- 3 and Bax, and decreased the cell viability and expression of BDNF in vitro. However, these changes were reversed by TREK-1 knockdown. Further investigation is required to elucidate the detailed signaling cascades that are involved in the regulation of TREK-1 in response to isoflurane exposure for different cell types, and to confirm the efficacy of TREK-1 knockdown in recovering cognitive dysfunction in vivo. The present results provide evidence that isoflurane-induced cognitive dysfunction may be associated with TREK-1 dysfunction in hippocampal astrocytes and provides a reference for the safe use of isoflurane anesthesia in infants and children.

\section{Acknowledgements}

The present study was supported by the National Natural Science Foundation (grant nos. 81571309 and 81401109) of China and Project of Science and Technology of Social Development in Shaanxi 21 Province (grant no. 2015SF005).

\section{References}

1. Sall JW, Stratmann G, Leong J, McKleroy W, Mason D, Shenoy S, Pleasure SJ and Bickler PE: Isoflurane inhibits growth but does not cause cell death in hippocampal neural precursor cells grown in culture. Anesthesiology 110: 826-833, 2009.

2. Ballesteros KA, Sikorski A, Orfila JE and Martinez JL Jr: Effects of inhaled anesthetic isoflurane on long-term potentiation of CA3 pyramidal cell afferents in vivo. Int J Gen Med 5: 935-942, 2012.

3. Zhang B, Tian M, Zhen Y, Yue Y, Sherman J, Zheng H, Li S, Tanzi RE, Marcantonio ER and Xie Z: The effects of isoflurane and desflurane on cognitive function in humans. Anesth Analg 114: 410-415, 2012.

4. Zhang F, Zhu ZQ, Liu DX, Zhang C, Gong QH and Zhu YH: Emulsified isoflurane anesthesia decreases brain-derived neurotrophic factor expression and induces cognitive dysfunction in adult rats. Exp Ther Med 8: 471-477, 2014.

5. Zhu C, Gao J, Karlsson N, Li Q, Zhang Y, Huang Z, Li H, Kuhn HG and Blomgren K: Isoflurane anesthesia induced persistent, progressive memory impairment, caused a loss of neural stem cells, and reduced neurogenesis in young, but not adult, rodents. J Cereb Blood Flow Metab 30: 1017-1030, 2010. 
6. Mellon RD, Simone AF and Rappaport BA: Use of anesthetic agents in neonates and young children. Anesth Analg 104: 509-520, 2007.

7. Shetty AK: Hippocampal injury-induced cognitive and mood dysfunction, altered neurogenesis and epilepsy: Can early neural stem cell grafting intervention provide protection. Epilepsy Behav 38: 117-124, 2014.

8. Zhao N, Zhong C, Wang Y, Zhao Y, Gong N, Zhou G, Xu T and Hong Z: Impaired hippocampal neurogenesis is involved in cognitive dysfunction induced by thiamine deficiency at early pre-pathological lesion stage. Neurobiol Dis 29: 176-185, 2008.

9. Kuhn HG, Dickinson-Anson H and Gage FH: Neurogenesis in the dentate gyrus of the adult rat: Age-related decrease of neuronal progenitor proliferation. J Neurosci 16: 2027-2033, 1996.

10. Donovan MH, Yazdani U, Norris RD, Games D, German DC and Eisch AJ: Decreased adult hippocampal neurogenesis in the PDAPP mouse model of Alzheimer's disease. J Comp Neurol 495: 70-83, 2006

11. Rubino T, Realini N, Braida D, Guidi S, Capurro V, Viganò D, Guidali C, Pinter M, Sala M, Bartesaghi R and Parolaro D: Changes in hippocampal morphology and neuroplasticity induced by adolescent THC treatment are associated with cognitive impairment in adulthood. Hippocampus 19: 763-772, 2009.

12. Kim TW, Choi HH and Chung YR: Treadmill exercise alleviates impairment of cognitive function by enhancing hippocampal neuroplasticity in the high-fat diet-induced obese mice. J Exerc Rehabil 12: 156-162, 2016.

13. Secchiero P, Melloni E, di Iasio MG, Tiribelli M, Rimondi E, Corallini F, Gattei V and Zauli G: Nutlin-3 up-regulates the expression of Notch1 in both myeloid and lymphoid leukemic cells, as part of a negative feedback anti-apoptotic mechanism. Blood 113: 4300-4308, 2009.

14. Schitine C, Nogaroli L, Costa MR and Hedin-Pereira C: Astrocyte heterogeneity in the brain: From development to disease. Front Cell Neurosci. 9: 76, 2015.

15. Barker AJ and Ullian EM: Astrocytes and synaptic plasticity. Neuroscientist 16: 40-50, 2010.

16. Jones OD: Astrocyte-mediated metaplasticity in the hippocampus: Help or hindrance. Neuroscience 309: 113-124, 2015.

17. Pabst M, Braganza O, Dannenberg H, Hu W, Pothmann L, Rosen J, Mody I, van Loo K, Deisseroth K, Becker AJ, et al: Astrocyte intermediaries of septal cholinergic modulation in the hippocampus. Neuron 90: 853-865, 2016.

18. Lin D and Zuo Z: Isoflurane induces hippocampal cell injury and cognitive impairments in adult rats. Neuropharmacology 61 : 1354-1359, 2011

19. Nie H, Peng Z, Lao N, Dong H and Xiong L: Effects of sevoflurane on self-renewal capacity and differentiation of cultured neural stem cells. Neurochem Res 38: 1758-1767, 2013.

20. Cheung SW, Nagarajan SS, Bedenbaugh PH, Schreiner CE, Wang $\mathrm{X}$ and Wong A: Auditory cortical neuron response differences under isoflurane versus pentobarbital anesthesia. Hear Res 156: 115-127, 2001

21. Noel J, Sandoz G and Lesage F: Molecular regulations governing TREK and TRAAK channel functions. Channels 5: 402-409, 2011.

22. Ehling P, Cerina M, Budde T, Meuth SG and Bittner S: The CNS under pathophysiologic attack-examining the role of $\mathrm{K}_{2} \mathrm{p}$ channels. Pflugers Arch 467: 959-972, 2015.

23. Lu L, Wang W, Peng Y, Li J, Wang L and Wang X: Electrophysiology and pharmacology of tandem domain potassium channel TREK-1 related BDNF synthesis in rat astrocytes. Naunyn Schmiedebergs Arch Pharmacol 387: 303-312, 2014

24. Patel AJ,Honoré E, Lesage F, Fink M, Romey G and Lazdunski M: Inhalational anesthetics activate two-pore-domain background K+ channels. Nat Neurosci 2: 422-426, 1999.

25. Wang $\mathrm{K}$ and Kong $\mathrm{X}$ : Isoflurane preconditioning induces neuroprotection by up-regulation of TREK1 in a rat model of spinal cord ischemic injury. Biomol Ther (Seoul) 24: 495-500, 2016.

26. Yin X, Su B, Zhang H, Song W, Wu H, Chen X, Zhang X, Dong H and Xiong L: TREK1 activation mediates spinal cord ischemic tolerance induced by isoflurane preconditioning in rats. Neurosci Lett 515: 115-120, 2012

27. Ye D, Li Y, Zhang X, Guo F, Geng L, Zhang Q and Zhang Z: TREK1 channel blockade induces an antidepressant-like response synergizing with 5-HT1A receptor signaling. Eur Neuropsychopharmacol 25: 2426-2436, 2015.
28. Olsen ML, Khakh BS, Skatchkov SN, Zhou M, Lee CJ and Rouach N: New insights on astrocyte ion channels: Critical for homeostasis and neuron-glia signaling. J Neurosci 35: $13827-13835,2015$

29. O'Callaghan EL, Bassi JK, Porrello ER, Delbridge LM, Thomas WG and Allen AM: Regulation of angiotensinogen by angiotensin II in mouse primary astrocyte cultures. J Neurochem 119: 18-26, 2011.

30. Panickar KS, Jayakumar AR, Rama Rao KV and Norenberg MD: Downregulation of the $18-\mathrm{kDa}$ trans-locator protein: Effects on the ammonia-induced mitochondrial permeability transition and cell swelling in cultured astrocytes. Glia 55: 1720-1727, 2007.

31. Lee J, Kim MS, Park C, Jung EB, Choi DH, Kim TY, Moon SK and Park R: Morphine prevents glutamate-induced death of primary rat neonatal astrocytes through modulation of intracellular redox. Immunopharmacol Immunotoxicol 26: 17-28, 2004.

32. Wang H, Xu Z, Feng C, Wang Y, Jia X, Wu A and Yue Y: Changes of learning and memory in aged rats after isoflurane inhalational anaesthesia correlated with hippocampal acetylcholine level. Ann Fr Anesth Reanim 31: e61-e66, 2012.

33. Liu J, Wang P, Zhang X, Zhang W and Gu G: Effects of different concentration and duration time of isoflurane on acute and long-term neurocognitive function of young adult $\mathrm{C} 57 \mathrm{BL} / 6$ mouse. Int J Clin Exp Pathol 7: 5828-5836, 2014.

34. Livak KJ and Schmittgen TD: Analysis of relative gene expression data using real-time quantitative PCR and the 2(-Delta Delta C(T)) method. Methods 25: 402-408, 2001

35. Uhrig L, Dehaene S and Jarraya B: Cerebral mechanisms of general anesthesia. Ann Fr Anesth Reanim 33: 72-82, 2014

36. Vlisides P and Xie Z: Neurotoxicity of general anesthetics: An update. Curr Pharm Des 18: 6232-6240, 2012.

37. DiMaggio C, Sun LS, Ing C and Li G: Pediatric anesthesia and neurodevelopmental impairments: A Bayesian meta-analysis. J Neurosurg Anesthesiol 24: 376-381, 2012.

38. Jevtovic-Todorovic V, Hartman RE, Izumi Y, Benshoff ND, Dikranian K, Zorumski CF, Olney JW and Wozniak DF: Early exposure to common anesthetic agents causes widespread neurodegeneration in the developing rat brain and persistent learning deficits. J Neurosci 23: 876-882, 2003.

39. Brambrink AM, Evers AS, Avidan MS, Farber NB, Smith DJ, Zhang X, Dissen GA, Creeley CE and Olney JW: Isoflurane-induced neuroapoptosis in the neonatal rhesus macaque brain. Anesthesiology 112: 834-841, 2010.

40. Zou X, Liu F, Zhang X, Patterson TA, Callicott R, Liu S, Hanig JP, Paule MG, Slikker W Jr and Wang C: Inhalation anesthetic-induced neuronal damage in the developing rhesus monkey. Neurotoxicol Teratol 33: 592-597, 2011

41. Wang SQ, Fang F, Xue ZG, Cang J and Zhang XG: Neonatal sevoflurane anesthesia induces long-term memory impairment and decreases hippocampal PSD-95 expression without neuronal loss. Eur Rev Med Pharmacol Sci 17: 941-950, 2013.

42. Mintz CD, Barrett KM, Smith SC, Benson DL and Harrison NL: Anesthetics interfere with axon guidance in developing mouse neocortical neurons in vitro via a $\gamma$-aminobutyric acid type $\mathrm{A}$ receptor mechanism. Anesthesiology 118: 825-833, 2013.

43. Mintz CD, Smith SC, Barrett KM and Benson DL: Anesthetics interfere with the polarization of developing cortical neurons. J Neurosurg Anesthesiol 24: 368-375, 2012.

44. Culley DJ, Boyd JD, Palanisamy A, Xie Z, Kojima K, Vacanti CA, Tanzi RE and Crosby G: Isoflurane decreases self-renewal capacity of rat cultured neural stem cells. Anesthesiology 115: 754-763, 2011.

45. Allen NJ, Bennett ML, Foo LC, Wang GX, Chakraborty C, Smith SJ and Barres BA: Astrocyte glypicans 4 and 6 promote formation of excitatory synapses via GluA1 AMPA receptors. Nature 486: 410-414, 2012.

46. Kucukdereli H, Allen NJ, Lee AT, Feng A, Ozlu MI, Conatser LM, Chakraborty C, Workman G, Weaver M, Sage EH, et al: Control of excitatory CNS synaptogenesis by astrocyte-secreted proteins Hevin and SPARC. Proc Natl Acad Sci USA 108: E440-E449, 2011.

47. Clarke LE and Barres BA: Emerging roles of astrocytes in neural circuit development. Nat Rev Neurosci 14: 311-321, 2013.

48. Hong S, Xin Y, HaiQin W, GuiLian Z, Ru Z, ShuQin Z, HuQing W, Li Y and Yun D: The PPAR $\gamma$ agonist rosiglitazone prevents cognitive impairment by inhibiting astrocyte activation and oxidative stress following pilocarpine-induced status epilepticus. Neurol Sci 33: 559-566, 2012. 
49. Thrane AS, Rangroo Thrane V, Zeppenfeld D, Lou N, Xu Q Nagelhus EA and Nedergaard M: General anesthesia selectively disrupts astrocyte calcium signaling in the awake mouse cortex. Proc Natl Acad Sci USA 109: 18974-18979, 2012.

50. Creed MS, Sun XY and Rona GG: Astrocytes protect against isoflurane neurotoxicity by buffering pro-brain-derived neurotrophic factor. Anesthesiology 123: 810-819, 2015.

51. Ryu YK, Khan S, Smith SC and Mintz CD: Isoflurane impairs the capacity of astrocytes to support neuronal development in a mouse dissociated co-culture model. J Neurosurg Anesthesiol 26 363-368, 2014.

52. $\mathrm{Yu}$ W, Zhu $\mathrm{H}$, Wang $\mathrm{Y}$, Li G, Wang $\mathrm{L}$ and $\mathrm{Li} \mathrm{H}$ : Reactive Transformation and Increased BDNF Signaling by Hippocampal Astrocytes in Response to MK-801. PLoS One 10: 0145651,2015

53. Rocha SM, Cristovão AC, Campos FL, Fonseca CP and Baltazar G: Astrocyte-derived GDNF is a potent inhibitor of microglial activation. Neurobiol Dis 47: 407-415, 2012.

54. Hong $\mathrm{Y}$, Zhao $\mathrm{T}$, Li XJ and Li S: Mutant Huntingtin impairs BDNF release from astrocytes by disrupting conversion of Rab3a-GTP into Rab3a-GDP. J Neurosci 36: 8790-8801, 2016.

55. Zhang XY, Chen DC, Xiu MH, Haile CN, Luo X, Xu K, Zhang HP, Zuo L, Zhang Z, Zhang X, et al: Cognitive and serum BDNF correlates of BDNF Val66Met gene polymorphism in patients with schizophrenia and normal controls. Hum Genet 131: $1187-1195,2012$.

56. Kuczewski N, Porcher C and Gaiarsa JL: Activity-dependent dendritic secretion of brain-derived neurotrophic factor modulates synaptic plasticity. Eur J Neurosci 32: 1239-1244, 2010.

57. Siuda J, Patalong-Ogiewa M, Żmuda W, Targosz-Gajniak M, Niewiadomska E, Matuszek I, Jędrzejowska-Szypułka $\mathrm{H}$ and Rudzińska-Bar M: Cognitive impairment and BDNF serum levels. Neurol Neurochir Pol 51: 24-32, 2017.

58. Dixon KJ and Sherrard RM: Brain-derived neurotrophic factor induces post lesion trans-commissural growth of olivary axons that develop normal climbing fibers on mature Purkinje cells. Exp Neurol 202: 44-56, 2006.

59. Willson ML, McElnea C, Mariani J,Lohof AM and Sherrard RM BDNF increases homotypic olivocerebellar reinnervation and associated fine motor and cognitive skill. Brain 131: 1099-1112, 2008.

60. Sun H, Zhang J, Zhang L, Liu H, Zhu H and Yang Y: Environmental enrichment influences BDNF and NR1 levels in the hippocampus and restores cognitive impairment in chronic cerebral hypo-perfused rats. Curr Neurovasc Res 7: 268-280, 2010.

61. Wu J, Zhang M, Li H, Sun X, Hao S, Ji M, Yang J and Li K: BDNF pathway is involved in the protective effects of SS-31 on isoflurane-induced cognitive deficits in aging mice. Behav Brain Res 305: 115-121, 2016.

62. Lu LX, Yon JH, Carter LB and Jevtovic-Todorovic V: General anesthesia activates BDNF-dependent neuro-apoptosis in the developing rat brain. Apoptosis 11: 1603-1615, 2006.

63. Xu H, Gao HL, Zheng W, Xin N, Chi ZH, Bai SL and Wang ZY: Lactational zinc deficiency-induced hippocampal neuronal apoptosis by a BDNF-independent TrkB signaling pathway. Hippocampus 21: 495-501, 2011.
64. Ji M, Dong L, Jia M, Liu W, Zhang M, Ju L, Yang J, Xie Z and Yang J: Epigenetic enhancement of brain-derived neurotrophic factor signaling pathway improves cognitive impairments induced by isoflurane exposure in aged rats. Mol Neurobiol 50: 937-944, 2014.

65. Wang WY, Luo Y, Jia LJ, Hu SF, Lou XK, Shen SL, Lu H, Zhang HH, Yang R, Wang H, et al: Inhibition of aberrant cyclin-dependent kinase 5 activity attenuates isoflurane neurotoxicity in the developing brain. Neuropharmacology 77: 90-99, 2014.

66. Campos FL, Cristovão AC, Rocha SM, Fonseca CP and Baltazar G: GDNF contributes to oestrogen-mediated protection of midbrain dopaminergic neurones. J Neuroendocrinol 24: 1386-1397, 2012

67. Cho HJ, Sung YH, Lee SH, Chung JY, Kang JM and Yi JW: Isoflurane induces transient anterograde amnesia through suppression of brain-derived neurotrophic factor in hippocampus. J Korean Neurosurg Soc 53: 139-144, 2013.

68. Tyler WJ, Alonso M, Bramham CR and Pozzo-Miller LD: From acquisition to consolidation: On the role of brain-derived neurotrophic factor signaling in hippocampal-dependent learning. Learn Mem 9: 224-237, 2002.

69. Lesage F, Terrenoire C, Romey G and Lazdunski M: Human TREK2, a $2 \mathrm{P}$ domain mechano-sensitive $\mathrm{K}+$ channel with multiple regulations by polyunsaturated fatty acids, lysophospholipids and Gs, Gi, and Gq protein-coupled receptors. J Biol Chem 275: 28398-28405, 2000.

70. Heurteaux C, Guy N, Laigle C, Blondeau N, Duprat F, Mazzuca M, Lang-Lazdunski L, Widmann C, Zanzouri M, Romey G and Lazdunski M: TREK-1, a K+ channel involved in neuroprotection and general anesthesia. EMBO J 23: 2684-2695, 2004.

71. Moha Ou Maati H, Veyssiere J, Labbal F, Coppola T, Gandin C, Widmann C, Mazella J, Heurteaux C and Borsotto M: Spadin as a new antidepressant: Absence of TREK-1-related side effects. Neuropharmacology 62: 278-288, 2012.

72. Borsotto M, Veyssiere J, Moha Ou Maati H, Devader C, Mazella J and Heurteaux C: Targeting two-pore domain $\mathrm{K}(+)$ channels TREK-1 and TASK-3 for the treatment of depression: A new therapeutic concept. Br J Pharmacol 172: 771-784, 2015.

73. Mazella J, Pétrault O, Lucas G, Deval E, Béraud-Dufour S, Gandin C, El-Yacoubi M, Widmann C, Guyon A, Chevet E, et al: Spadin, a sortilin-derived peptide, targeting rodent TREK-1 channels: A new concept in the antidepressant drug design. PLoS Biol 8: 1000355, 2010

74. Zhang HP, Sun YY, Chen XM, Yuan LB, Su BX, Ma R, Zhao RN, Dong HL and Xiong L: The neuroprotective effects of isoflurane preconditioning in a murine transient global cerebral ischemia-reperfusion model: The role of the Notch signaling pathway. Neuromolecular Med 16: 191-204, 2014.

75. Yin J, Li H,Feng $\mathrm{C}$ and Zuo Z: Inhibition of brain ischemia-caused notch activation in microglia may contribute to isoflurane post-conditioning-induced neuroprotection in male rats. CNS \& neurological disorders drug targets 13: 718-732, 2014. 